\title{
Indigenous peoples' rights to natural resources in Argentina: the challenges of impact assessment, consent and fair and equitable benefit-sharing in cases of lithium mining
}

\section{Pia Marchegiani, Elisa Morgera \& Louisa Parks}

To cite this article: Pia Marchegiani, Elisa Morgera \& Louisa Parks (2019): Indigenous peoples' rights to natural resources in Argentina: the challenges of impact assessment, consent and fair and equitable benefit-sharing in cases of lithium mining, The International Journal of Human Rights, DOI: $10.1080 / 13642987.2019 .1677617$

To link to this article: https://doi.org/10.1080/13642987.2019.1677617

Published online: 21 Nov 2019.

Submit your article to this journal

Q View related articles 5

View Crossmark data ¿ 


\title{
Indigenous peoples' rights to natural resources in Argentina: the challenges of impact assessment, consent and fair and equitable benefit-sharing in cases of lithium mining
}

\author{
Pia Marchegiani ${ }^{a, b}$, Elisa Morgera (10) ${ }^{c}$ and Louisa Parks ${ }^{d}$ \\ a'Latin American School of Social Sciences (FLACSO-Argentina), Buenos Aires, Argentina; ${ }^{b}$ FARN (Fundación \\ Ambiente y Recursos Naturales), Buenos Aires, Argentina; 'Law School, University of Strathclyde, Glasgow, UK; \\ ${ }^{\mathrm{d} S}$ Shool of International Studies and Department of Sociology and Social Research, University of Trento, \\ Trento, Italy
}

\begin{abstract}
This article explores the role of ILO Convention 169 in two cases in the context of the development of lithium mining projects in Argentina. The cases serve to illustrate the implementation challenges arising from the Convention obligations on environmental impact assessment, free prior informed consent and benefit-sharing for the protection of indigenous and tribal peoples' rights over natural resources pertaining to their lands. The cases also point to areas where improvements in implementation are needed in light of indigenous peoples' demands that are reflected in international guidance on human rights and the environment.
\end{abstract}

\section{ARTICLE HISTORY}

Received 5 August 2019

Accepted 19 September 2019

\section{KEYWORDS}

Environmental impact assessment; free prior informed consent; benefitsharing; indigenous and tribal peoples; human rights and the environment; lithium mining

\section{Introduction}

The ILO Convention No 169 recognises indigenous and tribal peoples' right to participate in the use, management and conservation of natural resources pertaining to their lands. This encompasses a right to participate in the benefits arising from these activities 'wherever possible', even where the State retains ownership or other rights to these resources. ${ }^{1}$ Benefit-sharing is linked with other obligations under ILO Convention 169: the assessments of social, spiritual, cultural and environmental impacts of planned development activities, good-faith consultation through indigenous peoples' representative institutions, and cooperation with indigenous peoples in adopting environmental protection measures in their territories. ${ }^{2}$ As a result of these inter-linked obligations, impact assessments serve to provide information necessary to carry out consultations and benefit-sharing negotiations with indigenous peoples, including with a view to cooperating with them on environmental protection in their territories.

These provisions of ILO Convention No 169 have proven influential on the InterAmerican Court of Human Rights' (IACHR) case law developed on the basis of the Saramaka case. ${ }^{3}$ In turn, the Inter-American jurisprudence has had a visible impact on the African framework on human rights, ${ }^{4}$ and global human rights processes. ${ }^{5}$ Environmental 
impact assessment (EIA), free, prior and informed consent (FPIC) and benefit-sharing have been repeatedly identified as key safeguards for indigenous and tribal peoples to determine their own social, cultural and economic development, and to enjoy their way of life in the face of proposed extractive industry activities in or near their lands. ${ }^{6}$ Equally, these obligations, together with effective participation in the management and monitoring of traditional territories, continued access and use compatible with environmental protection, have been invoked in the case of proposed conservation activities such as the establishment of protected areas, in indigenous lands. ${ }^{7}$ These obligations are triggered when proposed activities may threaten indigenous peoples' and local communities' physical or cultural survival: ${ }^{8}$ either because the proposed development project or conservation initiative concerns natural resources traditionally used by indigenous and tribal peoples; or because the extraction of natural resources (notably minerals) that are not traditionally used by indigenous peoples is likely to affect other natural resources that are. ${ }^{9}$

Against the background of these international developments, this chapter discusses the role of ILO Convention 169 in two case studies of lithium mining industry projects in Argentina. Both concern indigenous lands in the northwest of the country. In one case, at the Olaroz salt flats, mining has been underway since 2015. In the second, at Salinas Grandes salt flats, the process is at the exploration stage. In both cases, indigenous representatives expressed opposition to mining, though to different degrees, and used different methods to attempt to express their opposition. A discussion of cases on lithium mining is particularly interesting for questions of environmental justice. Lithium is central for transitions away from fossil fuel-based economies as a key component in batteries for electric cars (amongst many other uses). The cases we briefly explore here thus hint at a tension in how a global public good (the move to a low-carbon society) is to be obtained while seeking to ensure respect for local environmental justice (for the indigenous communities whose lands lithium is located in). In the remainder of this introduction we will sketch the complex legal and governmental landscape surrounding extractive industries in Argentina. We will then present an overview of policy and activities concerning lithium in the country by way of setting the scene for an exploration of the challenges in implementing the Convention, as well as indigenous peoples' demands that are reflected in international guidance on environmental impact assessment, free prior informed consent and benefit-sharing.

\section{Context - Argentina}

Argentina ratified ILO Convention 169 in 2000, and its Constitution gives supremacy to international human rights within the domestic legal framework. As a federal State, however, Argentina has allocated significant powers related to extractives to the provincial level, and provincial laws lag behind in the implementation of national and international law. ${ }^{10}$ In more detail, Argentina recognises its provinces as pre-existing the current federal State, and therefore provincial authorities automatically enjoy power over all areas that were not passed to the central federal government when Argentina was founded, including today also natural resources. Amendments to the Constitution in 1994 introduced the right to a healthy environment, ${ }^{11}$ and recognised the ethnic and cultural pre-existence of indigenous peoples and community rights over lands traditionally occupied by them. ${ }^{12}$ 
The first change opened the way for setting minimum standards for environmental protection at the federal level through different laws, including the 2002 General Environmental Protection Law ('Ley General del Ambiente' Law No. 25.675), which introduced environmental policy principles to be followed across all policy areas, along with various tools for environmental management. The following minimum standards concern environmental impact assessment (EIAs) processes. Within these, EIAs must be carried out and a report published before any activity with significant impacts either on the environment or on local populations' quality of life (or both). ${ }^{13}$ The EIA process should also include a participatory phase where citizens can discuss the proposed activity and its implications. If this requirement is not respected the process may be held null. Other minimum standards concern access to information: the EIA must include a statement from the proponent explaining the activity and its effects (or lack thereof) on the environment; a report identifying impacts and mitigation measures, timely provision of information for the participatory phase, and a public authority decision on the activity. More detailed legal requirements on EIAs can then be found at the provincial level. The provincial decree (decree 5722-2010) in Jujuy, the province where the two cases studies take place, names its Environmental Management Unit as the decision-making body for activities requiring an EIA. The Unit includes members from a number of provincial agencies (such as human rights, environmental management and industry) as well as non-governmental stakeholders (such as geologists and indigenous communities). Jujuy modified its procedure for lithium mining projects specifically in 2011, by declaring lithium a strategic natural resource for the province (in line with federal government policies seeking to industrialise lithium products). ${ }^{14}$ This added an additional review of the proposed project and impacts by an expert committee. Against this background, one of the emerging research questions is whether in the specific context of extractives on indigenous territories, relevant federal and provincial requirements for EIAs effectively support indigenous communities in taking part in decisions on extractive industry development on their territories, as opposed to merely allowing them to participate in a process already limited to a predetermined set of development options. As underscored by the Inter-American Court, for this to happen EIAs need to ensure the respect of indigenous traditions and culture, ${ }^{15}$ by including specific elements and methodologies in line with the Akwé: Kon Guidelines for the conduct of cultural, environmental and social impact assessment on proposed developments on, or likely to impact on, sacred sites and on lands and waters traditionally occupied or used by indigenous and local communities. ${ }^{16}$ These Guidelines have been adopted under the Convention on Biological Diversity, ${ }^{17}$ to which Argentina is a party, with a view to taking into account, in an integrated manner, indigenous peoples' rights over lands and waters, associated biodiversity, as well cultural aspects (such as traditional systems of natural resource use, customary laws on the distribution of resources, and opportunities for elders to pass on natural resource-related knowledge to youth). In addition, these guidelines call for considering not only negative impacts (such as potential damage to ways of life, livelihoods, wellbeing, and traditional knowledge) of proposed developments, but also possible positive implications from indigenous peoples' perspectives, including with regard to environmental sustainability and community well-being, vitality and viability.

The second change flowing from the 1994 Constitutional reform, the aforementioned recognition of the pre-existence of indigenous peoples and community rights, paved the 
way for the conferment of communal land rights to indigenous communities from provincial governments in Argentina. This, however, was not fully implemented across the country due to a number of reasons, including lack of information on indigenous communities (which self-identify as such), lack of State capacity, insufficient budget and lack of political will, so the situation remains unclear. ${ }^{18}$ In Jujuy Province, the situation regarding communal land rights is even more unclear due to confusion over land registries. The continuing lack of clarity around communal land ownership is of direct significance for the implementation of the ILO Convention 169 in the context of extractives. As noted by UN Rapporteur James Anaya, the Argentinean Mining Code 'requires the permission of the land "owners" to explore for minerals'. ${ }^{19}$ The Mining Code, on the other hand, does not contain any other requirement for consultation, although consultations with local communities during EIAs are required by the General Environmental Law and contribute to implement ILO Convention 169. Against this background, another emerging research question is whether, as underlined by the Inter-American Court and the Committee on the Elimination of Racial Discrimination, the Argentinean legal system ensures the 'active participation of indigenous communities concerned' in EIAs, ${ }^{20}$ including through the provision of adequate human, financial, technical and legal resources to support indigenous expertise in EIAs, proportionally to the scale of the proposed development. $^{21}$

The Argentinean Mining Code also concerns benefit-sharing. It stipulates that companies holding mining concessions must pay an annual fee to the relevant authority (either the national or provincial government) as defined by the federal government. ${ }^{22}$ This is in line with practice under the ILO Convention: while benefit-sharing should be established on a case by case basis, taking into account the circumstance of the particular situation of the indigenous peoples concerned, ${ }^{23}$ the ILO Supervisory Bodies have often focused on profit-sharing from extractive activities. ${ }^{24}$ UN Special Rapporteur Anaya, however, warned that 'benefit sharing must go beyond restrictive approaches based solely on financial payments which, depending on the specific circumstances, may not be adequate for the communities receiving them'. ${ }^{25}$ In particular, empirical evidence from case studies suggests that local communities often consider non-monetary benefits to exceed the importance of monetary benefits for their wellbeing. ${ }^{26}$ Furthermore, monetary benefits have in some cases had documented negative (including divisive) effects on communities where 'élite capture' has taken place (where some community members are exposed to undue influence and bribery and consent is unfairly obtained). ${ }^{27}$ What Anaya suggested instead is a focus on both monetary and non-monetary benefits, with a view to preserving some control over extractive activities. For instance, he pointed to a minority ownership interest for indigenous peoples in the extractive operations so as to participate in project decision-making and share in profits. ${ }^{28}$ Yet another emerging research question is whether, as underlined by international guidance adopted under the Convention on Biological Diversity, agreements focus on both monetary and non-monetary benefits with a view to ensuring cultural appropriateness. In particular, according to the Akwé: Kon Guidelines, benefit-sharing should include payment for environmental services, access to markets and diversification of income-generating opportunities for small and medium-sized businesses. ${ }^{29}$

There do not seem to be other general laws in Argentina that spell out benefit-sharing obligations arising from indigenous peoples' rights to natural resources. This is per se a 
serious gap, as justiciability rests on the obligation for States to enshrine international benefit-sharing obligations in national law to clarify that benefit-sharing is an entitlement, not a mere privilege, to effectively control natural resources without outside interference. ${ }^{30}$

The following case studies will show how these gaps and discrepancies in federal and provincial law intertwine with difficulties in implementation of the ILO Convention 169 at the provincial level.

\section{Case studies}

Before presenting the two cases, some basic information on lithium and mining in Argentina is useful. Lithium mining has been underway to a limited extent since 1997. However, global demand and interest in the metal has increased exponentially in recent years in parallel with calls and attempts to move away from a fossil fuel-based global economy. Lithium is the key component of li-ion batteries, used for example in electric cars, and seen as central to this move away from fossil fuels as imagined by many industries today. It is a metal that is technically challenging to extract, however, and one of the most important accessible sources is the 'lithium triangle', a cluster of salt planes located high in the Andes where the borders of Argentina, Bolivia and Chile meet. In 2016, Argentina became the fastest growing provider of lithium, with its global share increasing from $11 \%$ to $16 \%$, and further projects in the pipeline. ${ }^{31}$ The context for this increase is a concerted push by the federal government for growth in the mining sector more generally. For example, federal taxes on all mineral exports were removed in 2016. For lithium specifically, the federal government has also pushed projects for the production of lithium batteries (for example through the creation of public companies). ${ }^{32}$

\section{Olaroz}

The Olaroz case includes two projects for lithium mining. ${ }^{33}$ The first, the Sales de Jujuy project, began extraction in 2015 and accounts for 6\% of global lithium production with plans to expand from 2019. In the same area, the Minera Exar project is also moving forward and is at the time of writing ${ }^{34}$ the plant was to start the production stage. The area around these two projects is home to ten indigenous Atacama communities that traditionally rely on the land and its natural resources for their livelihoods, which include livestock keeping, small-scale mining, handicrafts and textiles work. In particular, water is a central resource of concern - the ecosystem in the area, which is 4300 metres above sea level and reliant on a closed water basin, is fragile. A main concern among communities about mining projects thus relates to the possible contamination of their fresh water supplies, due to the amount of water used in lithium extraction, and possible mixing between fresh and saltwater systems within the basins. ${ }^{35}$ However, the communities in the area are also in desperate need of employment and, often, basic services, making investments in economic ventures in the area attractive.

Research was conducted with three communities in the area, which not only hold their communal land tittle but their land falls within the area of the project as defined by the companies themselves. ${ }^{36}$ Not all communities in the area have their land directly affected by a project but rather indirectly due to the impact in a shared water source. The companies do not consider the other communities in the area as falling within this 
'area of direct influence', though all rely on the same water basin. Thus, they consult only those they consider in their direct area of influence.

The discussion is based on research by Marchegiani, Hoglund Hellgren and Gomez who interviewed community leaders and other members of communities to gauge their opinions and perceptions of the FPIC process.

In all three communities, the general shape of the process for seeking consent to move mining projects forward, first via explorations and then via actual building and extraction, have been similar. The companies concerned begin by contacting existing and recognised local authorities. In the three communities the basic form of organisation is comparable a local executive made up of a president and a committee (with varying names and formats) is elected every two years, and is responsible for carrying out decisions made in the local assembly, in which all adult residents have the right to take part. The populations of the communities vary from about 200 to 400, making this sort of direct participation possible, though not all residents do participate. Assemblies meet more or less on a monthly basis. Younger people not eligible to vote in the assembly are nevertheless encouraged to take part. Decisions are made by consensus, with simple majority votes used only where consensus cannot be reached.

The first point of call for companies seeking consent to begin mining on communallyowned lands is thus the President of the community. Following the EIA process, the company then presents its report to the community assembly, the body with the power to confer or deny consent. The companies attended series of assembly meetings in all three of the communities to present their projects, explain possible environmental impacts on the lands and local water supplies resulting from mining, and to discuss potential agreements on economic and employment benefits to be shared with local communities if mining were to go ahead, amongst other things. Consent for the Minera Exar project was given by the communities in Pastos Chicos and Huancar, but not (at the time of writing) by Olaroz Chico. Olaroz Chico has, however, given consent for the Sales de Jujuy project as the only community among the three consulted. Agreements about economic and employment benefits are also in place. Though the details remain confidential, interviewees talked about jobs (though often in sectors with little scope for promotion), capacity building and payments, as confirmed by Frankel and Whoriskey. ${ }^{37}$ In Pastos Chicos, benefits in the form of assistance for the construction of a secondary school, internet connection, and community celebrations was also provided.

Overall, the interactions between mining companies and communities did not run smoothly in the eyes of all community members. Three areas deserve discussion in light of both the focus on ILO Convention 169 and on the basis of the main themes that arose from community-level research: the reliability, accessibility and framing of information: the need for continuous, good-faith dialogue on FPIC and benefit-sharing; and the role of the State. Community members confirmed that companies provided EIA reports, and representatives were available to answer questions at community assemblies, though they noted that the availability and presence of company representatives declined after the community had given consent for the project. Ordinary community members raised other issues. First, some pointed out that relevant information was not made available early enough for proper consideration prior to assemblies, and the presence of company representatives was sometimes confirmed only shortly before a meeting. This affected communities' ability to give proper consideration to information 
and formulate questions. Second, the format of the information provided took the form of lengthy, written reports, generally held in hard copy for consultation by community members, which was stored by their elected representatives. Third, the use of highly specialist and technical language was used to convey the information at meetings. As a result of the last two issues, community members sometimes felt unable to ask the right questions as a result of feeling unable to fully grasp the content, while others who did ask questions found the answers delivered in similarly technical and impenetrable language. Some community members confirmed that they had not been asked what format they would prefer information to be in. The source of information provided was also raised as a key issue: all reports, whether on the mining project itself or on ecological matters, were provided by the mining companies. For some community members, this raised issues about the independence of the information and they expressed a wish to see information produced by others.

These community concerns align with relevant international human rights and environmental standards that can guide implementation of the ILO Convention 169. The Inter-American Court, for instance, has stressed that EIAs should be prepared by an independent, technically qualified entity with the 'active participation of indigenous communities concerned'. ${ }^{38}$ It has also clarified the relationship between EIA and FPIC, stating the latter should be based on an understanding of the full range of issues and implications entailed by the activity in question, founded in turn on 'full and objective information about all aspects of the project that will affect them, including the impact of the project on their lives and environment. ${ }^{39}$ While international guidance in the area of human rights remains quite abstract, international guidance agreed upon by Argentina in the context of the UN Convention on Biological Diversity (CBD) provides more detailed approaches to implementation. It emphasises, for instance, the need to use comprehensible language, to provide adequate and balanced information from a variety of sources, to use indigenous languages, to ensure that all parties have the same understanding of the information and terms provided; and to adopt culturally appropriate deadlines taking into account the time requirements of indigenous peoples. ${ }^{40}$

Added to the dilemmas of relying on one single source of information, some of the community members communicated with researchers also felt that the way that information was presented at assembly meetings was perhaps calculated to favour consent. Specifically, information about the project and possible environmental impacts was presented at the same time as information about possible benefits for the community in the form of payments and jobs. This, some felt, maximised the possible local benefits of the project while minimising its impacts. A division among community members in this vein concerns perceptions of the importance of benefits, and different understandings of what constitutes a benefit, brought by mining projects. Some community members see the economic, employment and other social benefits as crucial to the short and long-term survival of their households. Others in the community felt differently and that, on balance, the threats posed to their livelihoods by mining projects are greater that their potential benefits. Nevertheless, most community members raised concerns about the environmental impact of the projects, and whether benefits would continue in the long term. Some were skeptical about whether favourable outcomes were possible, expressing the opinion that negotiations would only move forward if some tacit promise about consent for future project stages was given. In the case of Sales de Jujuy, communities 
further afield had hoped that a broader approach could be taken to negotiating benefits, yet the company is at the time of writing pursuing talks on a community-by-community basis. There was thus some convergence of opinion about the need to continue dialogues with companies, particularly as projects moved towards the production stage, to make sure that agreements on benefit-sharing were updated and would endure over time. Once again, community concerns are reflected in international human rights and environmental standards, which emphasise that benefit-sharing should be culturally appropriate ${ }^{41}$ (on the basis of an early identification of benefits according to communities' worldviews in the EIA). ${ }^{42}$ All these steps are indispensable in seeking FPIC and negotiating benefitsharing as a continual, good-faith dialogue aimed at building a mutually beneficial, ongoing partnership, which is supported by international human rights bodies and reflected in international guidance adopted by Argentina under the CBD. ${ }^{43}$

Various issues and perceptions of the FPIC process discussed thus far point to where the state and its agencies, whether provincial or federal, could play a crucial role as a neutral facilitator and guarantor of human rights. No government representatives appear to have attended any of the meetings with the communities, despite the leader of one community specifically soliciting them. Some provincial government representatives were present at meetings held in larger local towns and the provincial capital. The general view of community members and leaders is that the absence of the State was felt most keenly in terms of access to full and independent information, particularly about potential impacts on local water supplies. Indeed, research by the national State ombudsman on provincial government capacity reveals that no baseline studies were commissioned or carried out. ${ }^{44}$ The absence of the State also carries into the period after consent is given, in particular in connection with the monitoring of water supplies. This again chimes with relevant international guidance that can support implementation of the ILO Convention. That said, community member participation in monitoring activities is challenging, both because of working time lost and because of the technicality of the activity.

Former UN Special Rapporteur Anaya clarified that States cannot delegate their responsibilities to business enterprises, particularly when the national regulatory framework regarding indigenous rights, including in relation to benefit-sharing, is insufficient or inexistent. ${ }^{45} \mathrm{He}$ emphasised that, notwithstanding companies' efforts in respecting indigenous peoples' rights,

the State remains ultimately responsible for any inadequacy in the consultation or negotiation procedures and therefore should employ measures to oversee and evaluate the procedures and their outcomes, and especially to mitigate against power imbalances between the companies and the indigenous peoples with which they negotiate. ${ }^{46}$

He added that States are to verify that agreements between indigenous peoples and extractive industries are crafted on the basis of full respect for indigenous peoples' rights and include provisions on impact mitigation and grievance mechanisms. ${ }^{47}$

Overall, the Olaroz case suggests that the power to shape the community-industry relationship through EIAs, FPIC and benefit-sharing in practice lies overwhelmingly with extractive companies, who define which communities they will consult with and for how long. Most importantly, the companies held a monopoly over the provision and thus the framing of information provided to communities as the basis for their 
decision. State agencies, as confirmed in research by the National Ombudsman's office, did not carry out their own research. Furthermore, mining companies dispose of resources that are valuable to the communities they negotiate with, and are aware of the services communities lack, which puts them at a clear advantage in negotiating benefit-sharing agreements. In addition, State agencies were not present to facilitate the dialogue between companies and communities, to guarantee the fairness and impartiality of the procedure. This is particularly important in a situation where domestic laws do not spell out in sufficient detail how to implement international standards on EIA, FPIC and benefit-sharing to ensure the effective protection of indigenous peoples' rights to natural resources.

\section{Salinas Grandes}

The second case concerns the Salinas Grandes and Laguna de Guayatayoc planes, where although there is no lithium mining taking place at the time of writing - a number of projects are in initial stages. ${ }^{48}$ In this case, the communities took a proactive approach to address the shortcomings in domestic legislation and implementation practices identified in the previous case. A large group of local Kolla and Atacama communities worked together to produce a community protocol called Kachi Yupi ('Tracks in the Salt') with a view to detailing their vision of a culturally appropriate FPIC procedure. This section builds on interviews carried out in 2015 and 2017 by the authors, as well as the longerterm research carried out by Marchegiani.

Exploration activities by mining companies seeking to extract lithium in the area began in 2010, and initial requests to begin an EIA for exploration activities were raised with provincial authorities. Local community members, however, do not appear to have been either informed or collectively consulted by any companies until recent months. The communities in the area were concerned from the beginning by the exploration activities and began to organise themselves, forming the Table of the Native Peoples of Salinas Grandes and Laguna de Guayatayoc (comprising representatives from 33 communities in the area). Their intention was specifically to address questions around FPIC and the wider recognition of indigenous communities, both as interlocutors on mining projects and more broadly as holders of rights to self-determination over what happens on their lands. The 33 communities meet on a rotating basis in different villages. Members are elected, and gender parity is ensured. From the larger group, a smaller executive body of 15 representatives has been selected. The 33 communities have long worked with community lawyers based in Jujuy to present their concerns in different ways. In particular, the group has filed complaints about not being consulted on mining projects before the courts in Argentina as well as the Inter-American Commission on Human Rights. ${ }^{49}$ In late 2011, the group also made representations to UN Special Rapporteur Anaya during his visit to the area, and to the UN Economic Social and Cultural Rights Committee in the same year. ${ }^{50}$

The 33 communities' work to define FPIC in their own specific terms raises questions in line with the discussion of the Olaroz case - the reliability, accessibility and framing of information: the need for continuous, good-faith dialogue on FPIC and benefit-sharing; and the role of the State. In order to define their view of a locally appropriate form of FPIC, the 33 communities drafted a community protocol. Such protocols are defined as 
'written documents in which indigenous peoples and local communities articulate their values, traditional practices and customary law concerning environmental stewardship, based upon the protection afforded to them by national and international environmental and human rights law. ${ }^{51}$ Community protocols have found increasing recognition under the above-mentioned Convention on Biological Diversity, with State Parties, including Argentina, agreeing that community protocols

provide communities an opportunity to focus on their development aspirations vis-a-vis their rights and to articulate for themselves and for users their understanding of their biocultural heritage and therefore on what basis they will engage with a variety of stakeholders. By considering the interconnections of their land rights, current socio-economic situation, environmental concerns, customary laws and traditional knowledge, communities are better placed to determine for themselves how to negotiate with a variety of actors. ${ }^{52}$

The 33 communities were supported by the same locally-based community lawyers in drafting the protocol, as well as by the Foundation for the Environment and Natural Resources (FARN, including one of the authors), and Natural Justice. The community protocol was drafted on the basis of community consultations with some support from these actors where requested. It uses the ILO Convention 169 amongst other legal sources as a basis for the articulation of the group's understanding of the content of consultation processes. The aim was to create a document that defined consultation in the context of the communities' culture. The document describes the history of the communities from their own point of view, their expectations regarding consultation and FPIC on the basis of international, national and provincial law, and details advice on how such procedures should unfold. The latter is presented in a comparison of FPIC with the stages of the salt cycle (including for example traditional ceremonies, preparation of trenches, harvest, and processing) that places the procedure on the footing of respect for the worldview held among the 33 communities. More broadly, the protocol was written as part of a wider struggle for the recognition of indigenous rights, as expressed in the text through the retelling of a history of oppression. ${ }^{53}$

Information is a central point in the community protocol, and recalls many of the themes raised in the Olaroz case. The 33 communities expressed the need to access information that is independent, and is not presented only by the companies, calling for other sources for comparison. With regard to FPIC, the protocol underlines that meetings should take place well in advance of any expected timeline for a community decision, that as many meetings as the community requires should take place, and that they should be agreed with the communities in locally accessible places and times. Moreover, communities prefer to have meetings take place in their own area. As for the format and style of information provided, the protocol specifies that complex and technical information of the type usually presented in standard EIAs should also be provided in other ways and idioms that facilitate community engagement - for example, through different media. Also, they require access to third parties such as lawyers and scientific experts which can help them understand and discuss the information. This is in in line with international guidance adopted under the $\mathrm{CBD}$ and offered by international human rights bodies discussed above ${ }^{54}$ on the quality and accessibility of information and the need for adequate support to indigenous peoples. 
The protocol also raises the need for good-faith dialogue with communities, rather than the mere provision and discussion of information, in the context of indigenous peoples' wider struggle for the recognition of their rights. In particular, the protocol underlines that there should be no expectation of consent, and that the basis of any consent must lie in a project's compatibility with Buen Vivir, which is described as 'the process of full communal life on our land. It is being one and the same with the communities from their very roots. To achieve Buen Vivir means knowing how to live and thus how to live with others'. ${ }^{55}$ The document also states that even where consent is given, it will become void if a project becomes incompatible with Buen Vivir. These references not only serve to emphasise the need to seek the 'free' consent of indigenous peoples without pressure, intimidation, manipulation or undue influence, as underscored by CBD guidance. ${ }^{56}$ The compatibility with Buen Vivir also arguably provides a backdrop for culturally appropriate negotiations on fair and equitable benefit-sharing as part of a genuine dialogue across different worldviews.

The protocol also reflects on the role of the State in a historical perspective. Argentina is seen as run by descendants of colonial powers who continue a history of exploitation of indigenous peoples through taxes and other means. The document describes the history of community struggle against colonial powers including battles, the forced migration that occurred with the arrival of a railway line in the area, and mining activities that saw many abandon traditional livelihoods. This history of oppression underlies the fundamental aim of the 33 communities to be recognised and allowed to enjoy their rights, including through proper consultation and FPIC. The historical context serves to substantiate the need for the State to ensure a heightened level of protection in the context of an FPIC process so that, as underscored by UN Special Rapporteur Anaya, benefit-sharing takes into account the 'significant social capital [indigenous peoples] contribute under the totality of historical and contemporary circumstances' ${ }^{57}$ In addition, the protocol calls upon the State to ensure both the transparency of the consultation process and genuine participation by indigenous communities, as well as necessary support to them.

After its conclusion in 2015, the Kachi Yupi community protocol was considered by the newly elected provincial government and mining permits for the Salinas Grandes area were suspended. A provincial decree that would have officially recognised the protocol was under discussion for three years, but was not passed. At the national level the document was also recognised by the National Ombudsman's office, which recommended all provincial agencies to use the protocol if and when consulting the communities in the area. Permits have now been reactivated, and three projects are at the exploration stage - yet the companies concerned have not shown willingness to follow the terms of the community protocol, which includes the condition that all communities in the area be consulted together, since the projects are set on a watershed that is one connected ecosystem. The companies have preferred instead to negotiate with each community individually, in a manner similar to that described for the Olaroz case. This raises further questions about the State, and specifically the need for domestic recognition (in legislation or before courts) of the value of community protocols as an expression of culturally accepted approaches to the contextual implementation of the international obligations on EIA, FPIC and benefit-sharing arising from the ILO Convention 169. Such domestic recognition, in addition, should be accompanied by adequate monitoring and enforcement efforts on the part of the State. 


\section{Reflections on ILO Convention 169 and FPIC 'on the ground'}

The ILO Convention 169 contains the most explicit treaty obligations on the protection of indigenous peoples' rights to natural resources in international law. The implementation of these obligations can now rely on a wealth of international guidance, both from the area of human rights and environmental law, that responds to a significant degree to the needs identified by communities themselves in the cases studies discussed in this chapter namely for EIA, FPIC and benefit-sharing to be culturally appropriate and endogenously defined in a specific context.

We have discussed two cases on the implementation of ILO Convention 169 in Argentina where similar issues arose around the respective roles of the State and of private companies with regard to the quality, accessibility and framing of information, and ongoing good-faith engagement with different worldviews in the efforts to obtain consent and identify fair and equitable benefit-sharing arrangements. In particular, the power to shape the community-industry relationship through EIAs, FPIC and benefit-sharing in practice lies overwhelmingly with extractive companies, who define which communities they will consult with, for how long and in what terms. Even when communities proactively set the terms for engagement through community protocols, companies may prefer other routes to obtain their content to extractives. In addition, companies dispose of resources that are valuable to the communities they negotiate with, and are aware of the services that communities lack, which puts them at great advantage in negotiating benefit-sharing arrangements.

Both cases, therefore, underscored the importance of the international responsibility of the State to develop sufficiently detailed laws on EIA, FPIC and benefit-sharing to ensure that substandard practices by private companies can be effectively monitored, identified as unlawful, and feasibly challenged within the domestic legal system. In particular, national laws need to provide more detailed provisions on EIAs that also include socio-cultural impact assessments and consideration of benefit-sharing at early stages of the assessment process, as well as clarifying that benefits to be shared should be in accordance with the worldviews and priorities of indigenous peoples, including by creating opportunities for some degree of control over the extractive project by the community. In addition, the State needs to monitor the application of domestic rules, including by intervening in interactions between companies and communities (Olaroz). State responsibility further entails recognising and supporting communities' proactive efforts to articulate culturally appropriate ways to perform consultation through community protocols (Salinas Grandes).

\section{Notes}

1. International Labour Organization (ILO), Convention No. 169 Concerning Indigenous and Tribal Peoples in Independent Countries, 28 ILM 1382 (1989), Article 15.

2. Ibid., Articles 7(3), 5-6, 7(4).

3. Case of the Saramaka People v. Suriname, Inter-American Court of Human Rights judgment (Interpretation of the Judgment on Preliminary Objections, Merits, Reparations and Costs), 28 November 2007; Elisa Morgera, 'Reflection on 2016 UN Biodiversity Conference (Part II): assessing the Mo'otz kuxtal guidelines on benefit-sharing from the use of traditional knowledge', BENELEX blog post (2017), https://benelexblog.wordpress.com/2017/03/01/ reflections-on-2016-un-biodiversity-conference-part-ii-assessing-the-mootz-kuxtal- 
guidelines-on-benefit-sharing-from-the-use-of-traditional-knowledge/ (accessed January 9, 2019).

4. Gaetano Pentassuglia, 'Indigenous Groups and the Developing Jurisprudence of the African Commission on Human and Peoples' Rights: Some Reflections', UCL Human Rights Review 3 (2010): 150-63, 158; African Court of Human and Peoples' Rights $v$ The Republic of Kenya, African Court of Human and Peoples' Rights App. No 006/2012, Judgement, 26 May 2017, para. 191.

5. James Anaya, Report of the Special Rapporteur on the Rights of Indigenous Peoples, Progress Report on Extractive Industries, UN Doc. A/HRC/21/47 (2012), paras. 52, 62; UN Expert Mechanism, Indigenous Peoples and Human Rights, Setting a Framework for Consultation, Benefit-Sharing and Dispute Resolution, UN Doc. A/HRC/EMRIP/2009/5 (2008); UN Expert Mechanism, Follow-up Report on Indigenous Peoples and the Right to Participate in Decision-making, with a Focus on Extractive Industries, UN Doc. A/HRC/21/55 (2012), para. 40; John Knox, Report of the Special Rapporteur on the Issue of Human Rights and the Environment John Knox: Framework Principles on Human Rights and the Environment, UN Doc A/HRC/34/49 (2017), principle 15.

6. Case of the Saramaka People v. Suriname, paras. 93-5; Case of Kaliña and Lokono Peoples v Suriname, Inter-American Court of Human Rights, Judgment (Merits, Reparations and Costs), 25 November 2015, para. 124; Mattias Århén, Indigenous Peoples in the International Legal System (Oxford: Oxford University Press, 2016), 93.

7. Case of the Saramaka People v. Suriname; James Anaya, Report on the Situation of Human Rights and Fundamental Freedoms of Indigenous People, UN Doc. A/HRC/15/37/ (2010), paras. 257-67. See also James Anaya, Report of the Special Rapporteur Anaya to the General Assembly, UN Doc. A/71/99 (2016), paras. 74 and 80, which does not refer to benefit-sharing as such, but to partnership building.

8. Case of the Saramaka People v. Suriname, paras. 122-3; Patrick Thornberry, Indigenous Peoples and Human Rights (Manchester: Manchester University Press, 2002), 282.

9. Case of the Saramaka People v. Suriname, paras. 155-8; Stefania Errico, 'The Controversial Issue of Natural Resources: Balancing States' Sovereignty with Indigenous Peoples' Rights', in Reflections on the UN Declaration on the Rights of Indigenous Peoples, eds. Stephen Allen and Alexandra Xanthaki (Oxford: Hard Publishing Ltd, 2011), 329-66.

10. Implementation gaps can be identified both in the implementation of international agreements and in the fulfilment of national legislation.

11. National Constitution of Argentina, Article 41: 'All inhabitants enjoy the right to a healthful, balanced environment fit for human development, so that productive activities satisfy current needs without compromising those of future generations, and have the duty to preserve the environment ...'.

12. National Constitution of Argentina, Article 75, point 17: 'To recognize the ethnic and cultural pre-existence of indigenous peoples of Argentina'.

13. Argentina General Environmental Protection Law ('Ley General del Ambiente') No. 25.675 (2002), Articles 11-13.

14. See Pía Marchegiani, Jasmin Höglund Hellgren and Leandro Gómez, Lithium Extraction in Argentina: A Case Study on its Social and Environmental Impacts (Buenos Aires: Fundación Ambiente y Recursos Naturales, 2018), https:/goodelectronics.org/wp-content/uploads/ sites/3/2019/05/DOC_LITHIUM_ENGLISH.pdf (accessed July 25, 2019).

15. Case of the Saramaka People v. Suriname, para. 41; Case of Kichwa Indigenous Community of Sarayaku v. Ecuador, Inter-American Court of Human Rights judgement (Merits and reparations), 27 June 2012, para. 206; Case of Kaliña and Lokono Peoples v Suriname, Inter-American Court of Human Rights judgment (Merits, Reparations and Costs), para. 215.

16. See Inter-American Court of Human Rights (IACtHR), Case of the Saramaka People v. Suriname, Inter-American Court of Human Rights judgment (Interpretation of the Judgment on Preliminary Objections, Merits, Reparations and Costs), 12 August 2008, para. 41 and fn 23, which appears confirmed in Committee on the Elimination of Racial Discrimination (CERD), Concluding Observations on the Combined Thirteenth to Fifteenth Periodic 
Reports of Suriname, UN Doc. CERD/C/SUR/CO/13-15 (2015), para. 26. See also Anaya, Report on the situation of human rights and fundamental freedoms of indigenous people, para. 73, and UN Expert Mechanism, Progress Report on the Study on Indigenous Peoples and the Right to Participate in Decision-making, UN Doc. A/HRC/15/35 (2010), para. 37.

17. Convention on Biological Diversity (CBD), Akwé: Kon Voluntary Guidelines for the Conduct of Cultural, Environmental and Social Impact Assessment Regarding Developments to Take Place on, or which are Likely to Impact on, Sacred Sites and on Lands and Waters Traditionally Occupied or Used by Indigenous and Local Communities, CBD Decision VII/16 F (2004), https://www.cbd.int/doc/publications/akwe-brochure-en.pdf (accessed January 8, 2019); Elisa Morgera, 'Dawn of a New Day? The Evolving Relationship between the Convention on Biological Diversity and International Human Rights Law', Wake Forest Law Review 54 (2018): 101-21.

18. This is also due to the fact that Law No. 26160 prevented land evictions during the process of land identification and title granting. Thus, the rules on land title transfers were extended for 5 years in 2009 to allow for a technical legal survey. In 2013, these rules were again prorogated until the end of 2017.

19. Anaya, Report of the Special Rapporteur on the Rights of Indigenous Peoples, Progress Report on Extractive Industries, 11.

20. Case of Kichwa Indigenous Community of Sarayaku v. Ecuador, para. 300; Case of Kaliña and Lokono Peoples $v$ Suriname, para. 214; CERD, para. 26.

21. Case of Kaliña and Lokono Peoples v Suriname, paras. 18, 64-6 and 70.

22. Argentinean Mining Code, Article 213.

23. ILO, Monitoring Indigenous and Tribal Peoples' Rights through ILO Conventions: A Compilation of ILO Supervisory Bodies' Comments 2009-2010 (Geneva: ILO, 2010), 95; ILO, Indigenous and Tribal Peoples' Rights in Practice: A Guide to ILO Convention No 169 (Geneva: ILO, 2009), 107-8.

24. ILO, Report of the Committee Set Up to Examine the Representation Alleging Non-Observance by Ecuador of ILO Convention No. 169, Doc. GB.282/14/4 (2001), para. 44(3).

25. Anaya, Report on the Situation of Human Rights and Fundamental Freedoms of Indigenous People, para. 80.

26. Rachel Wynberg and Maria Hauck, 'People, Power and the Coast: Towards an Integrated, Just and Holistic Approach', in Sharing Benefits from the Coast: Rights, Resources and Livelihoods, eds. Rachel Wynberg and Maria Hauck (Cape Town: University of Cape Town Press, 2014), 143-65, 158.

27. Case of Kichwa Indigenous Community of Sarayaku v. Ecuador, para. 186; Jérémie Gilbert and Cathal Doyle, 'A New Dawn over the Land: Shedding Light on Collective Ownership and Consent', in Reflections on the UN Declaration on the Rights of Indigenous Peoples, eds. Stephen Allen and Alexandra Xanthaki (Oxford: Hard Publishing Ltd, 2011), 289-328.

28. James Anaya, Report of the Special Rapporteur on the Rights of Indigenous Peoples, Report to the Human Rights Council. Study on Extractive Industries and Indigenous Peoples, UN Doc. A/HRC/24/41 (2013), para. 75.

29. CBD, Akwé: Kon Voluntary Guidelines, para. 46.

30. Case of Kichwa Indigenous Community of Sarayaku v. Ecuador, paras. 115 and 134.

31. See Marchegiani, Hoglund Hellgren and Gomez for a full discussion.

32. This trend has been reverted and stopped in the context of economic adjustment policies as from 2018.

33. This section draws on Marchegiani, Hoglund Helgren and Gomez, which provides further detail and information.

34. November 2018.

35. M. A. Marazuela and others, 'Hydrodynamics of Salt Flat Basins: The Salar de Atacama Example', Science of the Total Environment 651, no. 1 (2018): 668-83.

36. The Sales de Jujuy project is a joint venture by Orocobre (an Australian mining company), Toyota Tsusho (Japan) and JEMSE. The Minera Exar project is a joint venture by Lithium 
Americas Corp. and the Sociedad Quimica y Minera de Chile S.A. in which JEMSE also holds a minor share.

37. Todd C. Frankel and Peter Whoriskey, 'Tossed Aside in the 'White Gold' Rush', Washington Post, December 19, 2016, https://www.washingtonpost.com/graphics/business/batteries/ tossed-aside-in-the-lithiumrush/?tid=batteriesseriesnav (accessed January 9, 2019).

38. Case of Kichwa Indigenous Community of Sarayaku v. Ecuador, para. 300; see also Case of Kaliña and Lokono Peoples v Suriname, para. 214; CERD, para. 26.

39. Case of Kichwa Indigenous Community of Sarayaku v. Ecuador, para. 134.

40. CBD, Mo'otz Kutal Voluntary Guidelines for the Developments of Mechanisms, Legislation or Other Appropriate Initiatives to Ensure the 'Prior and Informed Consent', 'Free, Prior and Informed Consent' or 'Approval and Involvement', Depending on National Circumstances, of Indigenous Peoples and Local Communities for Accessing their Knowledge, Innovations and Practices Relevant for the Conservation and Sustainable Use of Biological Diversity, and for Reporting and Preventing Unlawful Appropriation of Traditional Knowledge, CBD decision XIII/18 (2016), https://www.cbd.int/decisions/cop/13/18/6 (accessed January 9, 2019); Morgera, 'Reflection on 2016 UN Biodiversity Conference (Part II): assessing the Mo'otz kuxtal guidelines on benefit-sharing from the use of traditional knowledge', BENELEX blog post (2017), https://benelexblog.wordpress.com/2017/03/01/reflections-on2016-un-biodiversity-conference-part-ii-assessing-the-mootz-kuxtal-guidelines-on-benefitsharing-from-the-use-of-traditional-knowledge/ (accessed January 9, 2019).

41. Case of the Saramaka People v. Suriname, para. 25; CBD, Refinement and Elaboration of the Ecosystem Approach, CBD Decision VII/II (2004), Annex I; CBD, Tkarihwaié:ri Code of Ethical Conduct to Ensure Respect for the Cultural and Intellectual Heritage of Indigenous and Local Communities Relevant to the Conservation and Sustainable Use of Biological Diversity, CBD Decision X/42 (2010), https://www.cbd.int/doc/publications/ethicalconductbrochure-en.pdf (accessed January 9, 2019), para. 14; United Nations (UN), Framework Principles on Human Rights and the Environment, UN Doc. A/HRC/37/59 (2018), para. 53.

42. CBD, Refinement and Elaboration of the Ecosystem Approach, paras. 24 and 35.

43. Elisa Morgera, 'Under the Radar: The Role of Fair and Equitable Benefit-Sharing in Protecting and Realising Human Rights Connected to Natural Resources', International Journal of Human Rights 23, no. 7 (2019): 1098-139; CBD, Mo'otz Kutal Voluntary guidelines, paras. 6, 8 and 23(a); UN, United Nations Declaration on the Rights of Indigenous Peoples, UN Doc. A/ RES/61/295 (2007), preambular para. 15; UN Expert Mechanism, Follow-up Report on Indigenous Peoples and the Right to Participate in Decision-Making, with a Focus on Extractive Industries, Annex, paras. 28 and C.1.b, para.5; James Anaya, Report of the Special Rapporteur on the Rights of Indigenous Peoples, Report to the Human Rights Council. Study on Extractive Industries and Indigenous Peoples, UN Doc. A/HRC/24/41 (2013), paras. 75-7 and 92; James Anaya, Report on the Promotion and Protection of All Human Rights, Civil, Political, Economic, Social and Cultural Rights, Including the Right to Development, UN doc. A/HRC/12/ 34 (2009), para. 53; Case of Kalina and Lokono Peoples v Suriname, Inter-American Court of Human Rights Joint Concurring Opinion of Judges Sierra Porto and Ferrer Mac-Gregor Poisot, 25 November 2015.

44. Virginia De Francesco, 'La Argentina Del Litio - La Imperiosa Necesidad de Contar con Informacion Confinable', in FARN Revista Pulso Ambiental No. 10, No Todo Che Brilla es LITIO (Bueno Aires: FARN, 2018), https://issuu.com/fundacion.farn/docs/revistapulso_ n10_06-08_ok (accessed January 8, 2019).

45. James Anaya, Report of the Special Rapporteur on the Rights of Indigenous Peoples, UN Doc. A/66/288 (2011), para.105.

46. Anaya, Report of the Special Rapporteur on the Rights of Indigenous Peoples, Report to the Human Rights Council. Study on Extractive Industries and Indigenous Peoples, para. 62.

47. Ibid., paras. 88 and 92; Elisa Morgera, 'The legacy of UN Special Rapporteur Anaya on Indigenous Peoples and Benefit-Sharing', BENELEX blog post (2014), https://benelexblog. wordpress.com/2014/05/29/the-legacy-of-un-special-rapporteur-anaya-on-indigenouspeoples-and-benefit-sharing/ (accessed January 9, 2019). 
48. Three projects are at the exploration stage (one in Laguna de Guayatayoc and two in Salinas Grandes), two at initial exploration stage (both in Salinas Grandes), and three at the prospecting stage (all in Salinas Grandes) (Marchegiani, Hoglund Hellgren and Gomez). The exploration stage triggers an EIA and ensuing FPIC requirements under the General Environmental Law.

49. Eliana Ferradás Abalo, Ana Laura Lobo and Julieta Lucero, Conflicto socioambiental en Salinas Grandes: Neoextractivismo, Resistencias y Nociones de Desarrollo en el Nuevo Escenario Político Regional (Villa María: Universidad Nacional de Villa María, 2016).

50. Ibid.

51. Louisa Parks and Elisa Morgera, 'The Need for an Inter-Disciplinary Approach to Norm Diffusion: The Case of Fair and Equitable Benefit-Sharing', Review of European, Comparative \& International Environmental Law 24, no. 3 (2015): 353-67, 356.

52. CBD, Mo'otz Kutal Voluntary guidelines, para. 19.

53. See Comunidades Indígenas de las Salinas Grandes y Laguna de Guayatayoc de Jujuy y Salta, Procedimiento de Consulta y Consentimiento Previo, Libre e Informado para las Comunidadades Indígenas de la Cuenca de Salinas Grandes y Laguna de Guayatayoc, November 15, 2015, https://cl.boell.org/es/2015/12/15/kachi-yupi (accessed November 20, 2018); Clemente Flores, 'Entre el Litio y la Vida: Comunidades Originarias y la Lucha por la Conservación del gua y de su Cultura', in FARN, Informe Ambiental Anual 2017 (Buenos Aires: FARN, 2017).

54. See CBD, Mo'otz Kutal Voluntary guidelines and Case of Kaliña and Lokono Peoples $v$ Suriname, Judgment (Merits, Reparations and Costs).

55. Comunidades indígenas de las Salinas Grandes y Laguna de Guayatayoc de Jujuy y Salta, 2, author's translation.

56. CBD, Mo'otz Kutal Voluntary guidelines.

57. Anaya, Report of the Special Rapporteur on the Rights of Indigenous Peoples, Report to the Human Rights Council. Study on Extractive Industries and Indigenous Peoples, para. 76.

\section{Acknowledgements}

Our thanks to the many local community members and others that took part in the research initiatives that inform this work. Any mistakes or misrepresentations remain our own. Thanks also to the editors of this special issue and reviewers for their comments on earlier drafts of this work. The article draws on research carried out under the BeneLex project (Benefit-sharing for an equitable transition to the green economy - the role of law) funded by the European Research Council (grant 335592).

\section{Disclosure statement}

No potential conflict of interest was reported by the authors.

\section{Funding}

This work was supported by European Research Council [grant number 335592].

\section{Notes on contributors}

Pia Marchegiani is a PhD Candidate at the Latin American School of Social Sciences (FLACSOArgentina) and Environmental Policy Director at FARN (Fundación Ambiente y Recursos Naturales). She lectures at FLACSO (Global Studies Programme) and at the University of Buenos Aires Law School (Environmental Law Legal Clinic). She researches on environmental and social dimensions of lithium mining in Argentina. 
Elisa Morgera is Professor of Global Environmental Law at Strathclyde University Law School, Glasgow, UK. She was the Principal Investigator of the BENELEX project on fair and equitable benefit-sharing (2013-2018).

Louisa Parks is Associate Professor of Political Sociology at the University of Trento's School of International Studies and Department of Sociology and Social Research. A research fellow on the BENELEX project on fair and equitable benefit-sharing (2013-2018), her book Benefit-sharing in Environmental Governance: Local Experiences of a Global Concept based on findings from the project will shortly be published by Routledge in open access.

\section{ORCID}

Elisa Morgera (1D) http://orcid.org/0000-0002-5234-8784 